\title{
Human elements and the pragmatic approach in the Australian, Scottish and Swedish standards for newly qualified teachers
}

\author{
Göran Fransson ${ }^{1}$ (D) Andrea Gallant ${ }^{2} \cdot$ Rachel Shanks $^{3}$
}

\begin{abstract}
Teacher standards are used in many countries, but it has been argued that there is a disconnection between the standards and teachers' everyday practices. Mega-narratives about teachers' practices have been recognised as powerful for educational change and when implementing and legitimising standards. In this comparative study, the standards for newly qualified teachers in Australia, Scotland and Sweden are analysed in order to determine the extent to which they contain human elements, here framed as contextual professionalism, and/or paradigmatic knowledge (Olson and Craig in Teach Coll Rec 111(2):547-572, 2009a). This comparison facilitates an exploration of how teachers' work is envisaged in the respective countries and what is expected or required from newly qualified teachers. The results indicate that the Australian and Scottish standards emphasise paradigmatic knowledge in teaching, whereas the now abandoned Swedish standards emphasise contextual professionalism in teaching.
\end{abstract}

Keywords Comparative research · Educational change $\cdot$ Mega-narrative $\cdot$ Newly qualified teachers · Policy borrowing $\cdot$ Teacher standards

Göran Fransson

gfn@hig.se

Andrea Gallant

andrea.gallant@deakin.edu.au

Rachel Shanks

r.k.shanks@abdn.ac.uk

1 Department of Education and Business Studies, University of Gävle, Gävle, Sweden

2 Faculty of Arts and Education, Deakin University, Burwood, Australia

3 School of Education, University of Aberdeen, Aberdeen, Scotland, UK 


\section{Introduction}

\section{Standards, mega-narratives and teacher quality}

It is argued that the "quality of teachers" is the most important school-related factor in pupils' learning (Hattie 2009, 2012). Teacher quality has become a meganarrative for education systems worldwide and appears to be a key argument as to why educational change and national professional teacher standards documents are necessary. For instance, it is claimed that teacher standards are useful tools for reflective practice, planning continuing professional development and promoting teachers' learning (Ingvarson 1998; Mayer et al. 2005).

The mega-narrative suggests that standards are a solution to a perceived teacher problem. Sachs (2003) identifies four key narratives in the promotion of standards and teacher accountability. The common sense context promotes standards as unproblematic and does not define what teachers should do and know. The quality assurance context is underpinned by arguments that standards promote accountability and that quality is assessable. The quality improvement context suggests that standards promote teachers' professional development. Finally, in the context of certification, licensing and control are used interchangeably. Quality assurance and quality improvement are used as arguments for teacher standards in Australia (Down 2012), Sweden (SOU 2008), Canada (Alberta Education 2013), the European Union (European Commission 2013) and in many US states (US Department of Education 2002; Colorado Department of Education 2017). In this study, the focus is on standards for newly qualified teachers (NQTs) in Australia, Scotland and Sweden.

In the assessment of a competent teacher, the expectations for teacher quality are embedded with explicit and implicit norms and values (Biesta 2009; Tuinamuana 2011). These norms and values have acted as research stimuli and for critiquing teaching standards. Critics have suggested that standards risk minimising professional voices when only bureaucrats or policymakers' interpretation of teaching and learning underpin their design (Imig and Imig 2008). This empirical critique has generally focused on how standards reduce complex competencies to (illusory) simplified aspects of practice (Clarke and Moore 2013; Delandshere and Arens 2001; Tuinamuana 2011). These manifest when the standards only define teaching practice as tangible acts and ignore the elusive components of the teaching and learning experience (Dall'Alba and Sandberg 2006; Groundwater-Smith and Sachs 2002; MacBeath 2008). The focus on teacher quality, standards and pupils' results may also divert attention from other important factors (Smith 2008). When standards are too detailed they may be regarded as instrumental and lead to fragmented practices (Forde et al. 2016). One way of encouraging teachers' enactment of national standards has been to involve them in their development so that they are more likely to be endorsed by the profession (Mayer et al. 2005). However, in the Australian context, this claim has been refuted in a report showing that experienced teachers are less likely to use them (Australian Institute for Teaching and School Leadership 2015). 
Critics have also highlighted the way in which standards over-simplify what constitutes teachers' capabilities (Goodwin 2008). This raises the question of how teachers' practices can be fairly assessed by a universal standard, especially as empirical research has shown this to be almost impossible (Berliner 2005; Mahony and Hextall 2000). Indeed, Biesta (2009) questions whether teacher standards can really measure valuable competencies and challenges the field to consider:

whether we are indeed measuring what we value, or whether we are just measuring what we can easily measure and thus end up valuing what we (can) measure. (Biesta 2009, p. 35)

Measuring is a method that is often used to produce knowledge. However, measured data requires interpretation, in order to develop understanding. Bruner (1986) recognises two — narrative and paradigmatic_-sensemaking processes. The narrative mode deals "with human or human-like intentions and actions" (p. 13) and produces contextualised meaning by making entities and frames. The paradigmatic mode deals with general causes and "makes use of procedures to assure verifiable reference and to test for empirical truth" (p. 13). It has been argued that this produces decontextualised ways of knowing (Olson and Craig 2009a, b). On the other hand, it could be said that the narrative elements downplay paradigmatic knowledge and general experience of the empirical world. The difficulty is not paradigmatic knowledge in itself, but rather when it is not balanced with narrative processes.

The perceived problem with the dominance of paradigmatic knowledge is that it downplays teachers' professional and personal narratives (Bruner 1986). For example, an analysis of teacher standards in Australia, Canada (British Columbia), the USA (California), England and New Zealand shows that they fail to address culturally diverse students and culturally responsive teaching (Santoro and Kennedy 2016). In the Scottish context, McNally et al. (2008) question whether the Standard for Full Registration can "capture the essence of classroom teaching" for NQTs and whether it is a useful "reference for them in making sense of their everyday teaching, at that stage of development" (p. 288). However, advocates of teacher standards have presented an almost linear argument of causation, e.g. standards $=$ teaching quality $=$ improved student outcomes. This view of teaching and learning draws solely on paradigmatic knowledge (Bruner 1986; Olson and Craig 2009b).

Paradigmatic knowledge regarding education is "more subject to policy than to local conditions of the workplace or other shaping influences" (Olson and Craig 2009a, p. 548). As shown above, critics have argued that standards should reflect contextual matters and that teaching and learning require a complex pedagogy in order to be mindful of, and responsive to, how past and future events unfold over time (cf. Dall'Alba and Sandberg 2006; Groundwater-Smith and Sachs 2002; MacBeath 2008). The standards' nomenclature and focus highlight which aspects are regarded as important in the macro political discourse. In this sense, they are "neither neutral nor impartial" (Down 2012, p. 77; Forde et al. 2016) for accountability purposes (Broadbent and Gallagher 2013; Møller 2009; Santoro et al. 2012). Standards remain contested, because it is still not known how much they can 
convey context and paradigmatic knowledge. Against this background, standards could facilitate an unquestioned adoption of what is privileged as valuable. Hence it is particularly important to uncover the standards' embedded narratives, because what is valued may not always be desirable (Halverson and Clifford 2006). Consequently, the power of standards to construct an NQT's conception of what is valued should not be underestimated.

\section{Comparing standards}

This comparative study focuses on the extent that the NQT standards in Australia, Scotland and Sweden reflect context and paradigmatic knowledge (Olson and Craig 2009a). Teacher standards have become commonplace in many countries. Scotland was an early adopter of teacher standards for NQTs with the introduction of the Standard for Full Registration in 2002, which was revised in 2006 and 2012 (GTCS 2002, 2006, 2012). Australia only introduced national standards for NQTs in 2013. Prior to this, individual states and territories could decide whether or not to have standards. ${ }^{1}$ Sweden was also a late adopter of compulsory teacher standards; they were introduced in 2011, but discontinued in 2014 (see below).

These different national contexts provide a useful comparison of a meganarrative presence by looking for similarities in content between early and late adopters. Australia and Sweden are chosen as late adopters of national standards. Australia is also chosen due to the previous existence of state and territories having the autonomy to use standards or not. Sweden is chosen not because there is no earlier experience of national or regional standards but because the country abandoned these standards after 3 years. This may indicate a break with the Global Educational Reform Movement (Sahlberg 2010).

We use the term NQTs because this more accurately describes teachers who have successfully fulfilled graduate standards and have begun to teach but are not yet fully registered practitioners. Our focus is on the extent to which what we term contextual professionalism and paradigmatic knowledge are reflected in the standards, potentially revealing a mega-narrative positioning NQTs and their practice.

\section{Mega-narratives}

It is argued that teacher standards have been influenced by a neo-liberal ideology, which in the last 30 years has become a dominant global ideology with its emphasis on a free market, competition, accountability and performativity (Exley et al. 2011; Lingard 2010). The adoption of a neo-liberal ideology in the public sector has led to the new public management model (Tolofari 2005). These developments have been combined with calls for international competitiveness from influential policy

\footnotetext{
${ }^{1}$ Notably, in some countries teacher standards have been developed by initiatives from teacher associations, such as teacher unions, wanting to gain or retain some control over their profession. Examples of this can be found in Australia (The Australian Association of Mathematics Teachers Inc. AAMT) and in Sweden (Ethics of Teachers, The Swedish Teachers' Union and The National Union of Teachers in Sweden).
} 
organisations, such as the European Union, the OECD and the World Bank (Exley et al. 2011). This in turn has led to policy borrowing between countries, which requires legitimacy. When policies like teacher standards are borrowed, it is often stressed that policy learning and adjustments to the adopters' context are necessary (Chakroun 2010; Lingard 2010). Local adjustments are also questioned, since the policy-borrowing environment is fuelled by mega-narratives. Mega-narratives are recognised as having "a large and loose set of ideas about how society works, why it goes wrong and how it can be set right" (Cohen and Garet 1975, p. 21). Meganarratives are often superimposed on national and local settings, under the pretext that the issue being addressed is not local, but international (Olson and Craig 2009a). In this sense, mega-narratives play a paradigmatic role in constructing problems and solutions; a rhetoric that legitimises and normalises policy borrowing for educational change. The performativity and accountability policy initiatives by the Global Educational Reform Movement (Sahlberg 2010) are viewed by Olson and Craig (2009a, b) as a paradigmatic mega-narrative.

Olson and Craig's (2009a, b) research on accountability in balance led them to empirically investigate what they term the human elements alongside the paradigmatic mega-narrative in education (this can be aligned with Bruner's narrative and paradigmatic processes). For Olson and Craig (2009a, b), the human element is associated with teachers' working lives. A slightly different framing of human elements in this paper is presented as the contextual professional. The term professional is understood here as the action of a person who makes contextual judgements and decisions, rather than someone who follow general instructions based on paradigmatic knowledge.

The mega-narrative is underpinned by grand ideas about how education needs to work and what has to be addressed regarding functional improvement (Olson and Craig 2009a; Cohen and Garet 1975). The emphasis on the functionality of teaching and learning is identified by Olson and Craig (2009a) as a consequence of paradigmatic knowledge. They argue that mega-narratives of paradigmatic knowledge tend to be the drivers of policy reform, standardisation and improvement models. Olson and Craig (2009a) also note that these mega-narratives overshadow "the human elements", and result in "local conditions of the workplace or other shaping influences" being rendered invisible (p. 548). If a paradigmatic 'reality' is only presented to NQTs, it gives rise to questions about how it will position their professional development and decisional capital. The paradigmatic in this paper is when context and decisional capital are downplayed or ignored, as it implies that teachers are able to employ a predetermined set of behaviour without having to use contextual information or rely on their own professional knowledge.

\section{Research question}

Our research focuses on how the NQT standards are formulated in different national, cultural and educational contexts. We specifically look at whether there are discernible differences between representing teachers as professionals, where 
context matters, or if paradigmatic knowledge is being overly represented in the standards that countries set for their NQTs.

\section{Background to teacher standards in Australia, Scotland and Sweden}

In order to understand the manifestation of professionals in context and paradigmatic knowledge in the different standards documents, it is important to first outline each country's implementation of teacher standards.

In Australia, uniform teaching standards were only introduced nationally in 2013. Prior to this, state/territory education regulatory bodies could choose could choose whether to have standards, and if they did, how university teacher graduates needed to meet their requirements for registration/certification. In the early 1990s, a narrative emerged that uniform teaching standards were needed. In 2003, the National Goals for Schooling in the twenty-first Century (The Adelaide Declaration) were adopted, which emphasised the need to: enhance the status and quality of the profession and improve public confidence through professional standards that increase students' attainment (Timperley 2011). These goals were used to measure/ evaluate school effectiveness, efficiency and equity strengthened accreditation for teachers through nationally recognised and valued professional teaching standards (Timperley 2011). The move towards national teacher standards was influenced by international comparative studies, such as the Programme for International Student Assessment (PISA), Trends in International Mathematics and Science Study (TIMMS) and in particular the 2009 PISA results (Waldow et al. 2014).

In Scotland, the Standard for Full Registration was implemented in 2002 as part of a major reorganisation of teacher education and teachers' work. Between 1967 and 2002, head teachers were responsible for indicating whether they recommended a new teacher to be registered with the General Teaching Council for Scotland (GTCS) (Draper and O'Brien 2006). In 1997, research indicated that the quality of teacher probation was an issue (Draper et al. 1997), which led the Scottish Executive Education Department and the General Teaching Council for Scotland to establish the Teacher Induction Project. These bodies considered the arrangements for new teachers and drafted standards that needed to be met during their probation period (Christie and O'Brien 2005). This work developed into the first iteration of the Standard for Full Registration, which was revised in 2006 and 2012 (General Teaching Council for Scotland 2002, 2006, 2012).

In Sweden, the development of teacher standards was influenced by national and international circumstances. In the late 1990s and early 2000s, an educational crisis narrative dominated in Sweden. This was partly due to political rhetoric and declining international comparative results, e.g. PISA and TIMMS (Nordin 2014). In 2006, the newly elected centre-right alliance government instigated a major restructuring of the Swedish educational system, which resulted in a greater emphasis on quality, control, national tests and standards. In 2008, a Government Inquiry recommended teacher registration standards, an induction year for NQTs with mentors and a national standards evaluation of NQT competence (SOU 2008). These aspects were implemented in 2011, although the evaluation and teacher 
standards were abolished in 2014. This policy retreat was due to practical application problems, with not all NQTs being offered probation placements with evaluations during the induction year.

The mega-narrative explanations for declining student achievements in both Australia and Sweden were strongly influenced by neo-liberal ideas and mediated by (some) politicians and media outlets (Waldow et al. 2014). This was used to legitimise the policy borrowing of standards as a strategy for educational reform (Waldow et al. 2014; Nordin 2014). While Australian educational policymakers have traditionally used the United Kingdom and the United States as key references (Waldow et al. 2014), the Swedish system was primarily influenced by Scotland and Canada (SOU 2008). Policy borrowing around teacher standards has been less evident in Scotland, where the origins of professional standards can be traced back to 1992 (Forde et al. 2016).

Although teacher standards are no longer used for the assessment of NQTs in Sweden, the concept of standards has been further developed in Scotland and Australia. In Scotland, the Standard for Full Registration sits alongside the Standards for Provisional Registration, Career-long Professional Learning, Middle Leadership and Headship. In Australia, there are standards for graduate teachers, proficient teachers (NQTs), leading teachers and now principals.

Teacher registration is compulsory in Australia. In Scotland, registration is compulsory for teachers in publicly funded schools and from 1st October 2017 it became compulsory for teachers in fee paying schools. In both Scotland and Australia, those graduating from initial teacher education must demonstrate that they have met the national standards required to enter the profession and, on so doing, receive provisional registration. For 1 year at full-time, or 2 years at parttime, NQTs are expected to produce evidence that includes observations of their teaching practices in order to show that they have met the standards for full registration.

\section{Conceptual framing of the research}

\section{Contextual professionalism and paradigmatic knowledge}

The NQT standards are the artefacts under analysis. We have chosen Olson and Craig's (2009a, b) unique conceptual framing because it has not been applied to teacher standards and because, in our view, it offers an insightful way of critically examining the standards. Their conceptual framing consists of two key themes (human elements and paradigmatic knowledge). Each theme consists of four categories (see Appendix for a description). Olson and Craig's categories are used as identification codes that can be critically analysed.

The categories making up their concept of human elements are:

1. The past informs the present and future events unfold over time

2. Person in the process of change

3. Meaning behind actions-considering personal and social contexts 
4. Person in context (Olson and Craig 2009a, p. 550).

What this worldview privileges is that human endeavours cannot always be measured and that everything cannot be reduced to a universal case. We understand the human element as the professional making contextual decisions.

The contextual professionalism represents teachers and students as individuals and as part of a group or community. Teachers and/or students are presented as being in a process of change and not as static entities. Olson and Craig' (2009a) focus on the teacher/student as people in a relational and complex teaching and learning environment.

The categories portraying paradigmatic knowledge are:

1. Casual links are emphasised

2. Theoretical ideas, and technical procedures emphasised/valued

3. A view that actions are directly evident

4. Looking for generalisability-universal case (Olson and Craig 2009a, p. 550; cf. Olson and Craig 2009b).

These four categories highlight how a phenomenon is understood in order to produce knowledge, which then informs which actions/strategies to apply. Paradigmatic knowledge attempts to elicit teaching and learning patterns by emphasising explicit procedures and generalisability.

\section{Methodology and methods}

Although teacher standards have been strongly criticised, this study offers a new understanding by not replicating previous work. A content analysis of the NQT standards across three countries is undertaken in order to identify the presence and frequency of human elements and paradigmatic knowledge.

\section{Data sources}

Data sources consist of the Australian Standards for Proficient Teachers (Australian Institute of Teacher and School Leadership 2015), Scotland's Standard for Full Registration (GTCS 2012) and Sweden's Standards for Newly Qualified Teachers (Statutes of the National Agency for Education 2011).

\section{Data translation and phases of analysis}

The Swedish text was translated into English to facilitate a more reflective comparative analysis across the texts. One of the authors undertook the translation and then worked with a professional translator to compare their translations with the original Swedish text. The translators discussed concepts and definitions in order to arrive at accurately contextualised words and meanings. The professional translator 
has considerable multilingual experience of working with policy texts, educational research papers, ethnology and history.

After the translation process, the formulations of the three sets of standards were examined for evidence of teachers and students being represented as individuals and as part of a learning community. The contextual professionalism theme was recognised when the standards were formulated in a way that reflected teaching and learning environments as complex and relational. Paradigmatic knowledge was identified when teachers' work was emphasised as technical. The paradigmatic knowledge of the mega-narrative was also identified when there was a strong emphasis on measurable evidence.

The standards were analysed in two phases:

Phase 1: word frequency analysis of the three standards.

Phase 2: independent coding of the three standards, line-by-line, identifying Olson and Craig's (2009a) categories (as noted above) and triangulation of coding.

The computer assisted qualitative data analysis software package NVivo 10 (Paulus et al. 2014) was used to store the standards documents, perform word frequency searches, code the standards against the predetermined codes of human elements and paradigmatic knowledge and check for inter-coder reliability.

Phase 1: Word frequency queries

First, a word frequency was combined with a latent content analysis (Hsieh and Shannon 2005) focusing on the interpretation of content to discover underlying meaning (Miles et al. 2014). Our premise was that a dominant nomenclature would indicate the presence of contextual professionalism or paradigmatic knowledge. For this analysis, the standards' introductions and headings were excluded. Consideration was given to the different ways of conducting a word frequency query: (a) with exact words, (b) with stemmed words and (c) with synonyms grouped together. After analysing the different outcomes of the three different types of inquiry, the stemmed words (e.g. student and students combined) proved to be the most fruitful and generated the fifteen most frequently used words, which were then cross-checked in phase two.

Phase 2: Coding by contextual professionalism and paradigmatic knowledge categories

Initially, each researcher coded their own country's teacher standards and those of one other country line by line (see below). A description for each code was provided (see Appendix) in line with Olson and Craig (2009a, b) and agreed on by all the researchers. One researcher created codes for contextual professionalism and paradigmatic knowledge in NVivo.

The sets of codes were cross-checked to guarantee consistency in our interpretations of the standards, category codes and the application of the codes to the standards. Once we agreed on the coding, all three standards were coded in NVivo by one researcher and separately manually coded by another. This manual coding was then transferred into NVivo in order to check for inter-coder reliability. 
A coding comparison query was performed in NVivo (Bazeley and Jackson 2013), which showed a coding agreement of over $70 \%$ for all but one of the codes, namely 'person in context'. A review of the two sets of coded data indicated that this occurred because less text had been selected for coding by one of the researchers.

\section{Results}

\section{Introduction and length of the standards documents}

Before looking at the results, it is important to note that the three countries' standards differ in length and organisation. Scotland's standards document is the most extensive, with 1942 words organised in 23 different sections. The Australian standards consist of 952 words in seven sections, whereas the Swedish standards have 613 words in four sections. Thus, the Scottish standards are double the length of the Australian standards and more than four times as extensive as Sweden's.

Phase 1: Word frequency query results

Due to the differences in the number of topics addressed and the level of detail across the three countries' standards, a word frequency analysis was undertaken as the starting point in order to analyse dominant nomenclature. For this, section headings were excluded and stemmed words were grouped together, e.g. "student" covered "student, students' and students". The verb "use" was included because it related to paradigmatic knowledge in the standards. Table 1, below, shows the 15 most frequently stemmed words.

When these results were examined in terms of contextual professionalism and paradigmatic knowledge the Australian standards aligned more closely with the paradigmatic. The Scottish standards were not dissimilar in this respect. The Swedish standards differed from those of the other two countries in that contextual professionalism was more apparent.

One distinction is that the Swedish standards only include strategy/strategies once in the document. In comparison, strategies, is used frequently in the Australian standards (appearing 11 times in the text). The Scottish standards have a greater emphasis on strategy than the Swedish ones, but less so than Australia's (appearing only five times in the text). The Australian emphasis on teaching as a technical strategy with causal links is interpreted as positioning NQTs' practices as paradigmatic. An example of this is the directive to NQTs to "use effective verbal and non-verbal communication strategies to support student understanding, participation, engagement and achievement" (standard 3.5). In the Australian standards in particular, strategies are emphasised, even with regard to developing relationships.

References to student/s are frequent in both the Australian and Swedish standards, but appear only once in the Scottish standards, where the most frequent term is learner. The references to student/s are used differently in both the Swedish and Australian standards. In the Swedish standards, students are regarded as part of the human element of teaching. Here NQTs are encouraged to view students as 


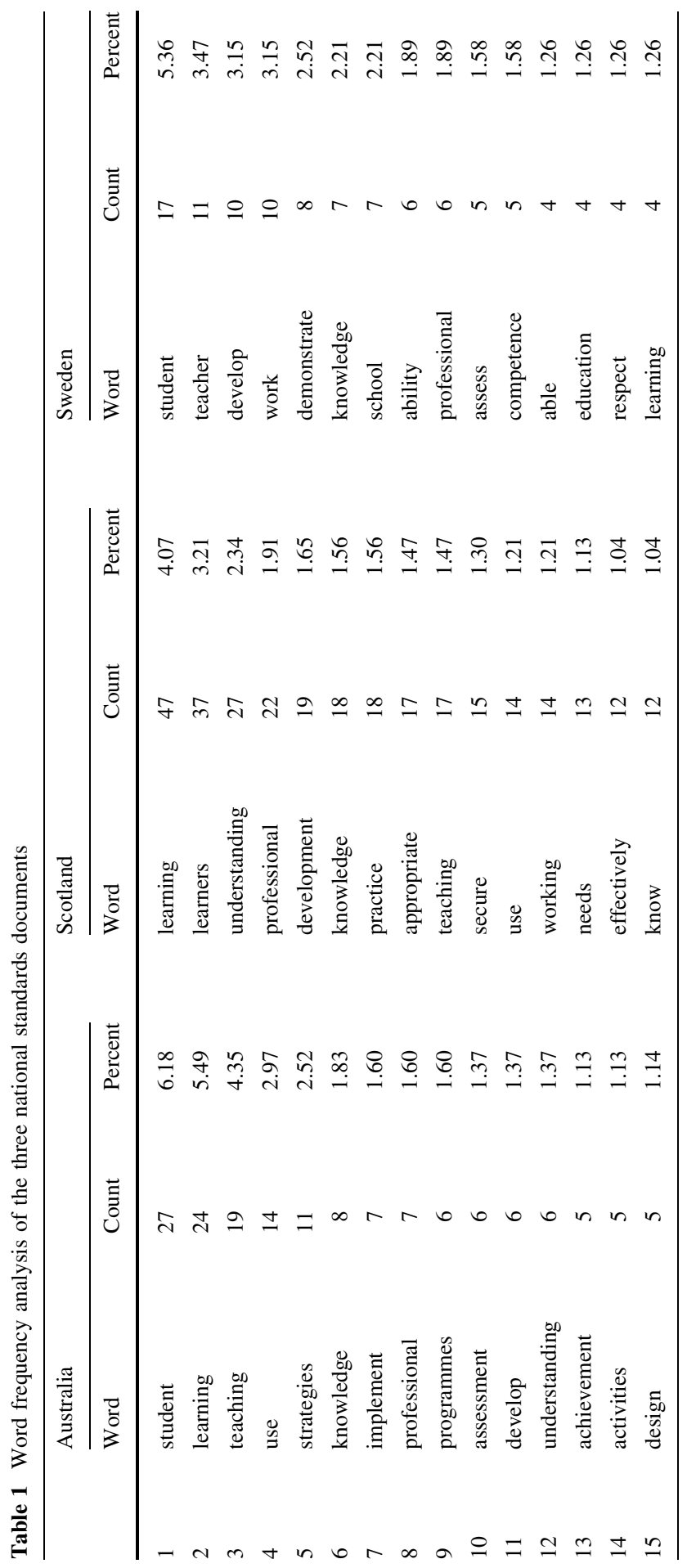


people they engage with in a learning partnership. For example, Swedish NQTs are expected to "discuss with the student what knowledge he or she should be able to develop" (17.3) and "involve the student in planning" (17.4) while striving "towards a good relationship with students that is characterised by mutual respect and trust" (17.4). This contrasts with the Australian standards, where students are largely projected as objects for the NQT to direct. For instance, the NQT is expected to "set explicit, challenging and achievable learning goals for all students" (3.1). The Scottish standards, on the other hand, appear to take a less paradigmatic stance towards learners. Here the emphasis is on establishing "...a culture where learners meaningfully participate in decisions related to their learning and their school" (3.1.5).

Learning is the most frequently used word in the Scottish standards and appears as the second most common term in the Australian standards. The Swedish standards, differ significantly, as learning only explicitly appears three times. This difference is interpreted as the Australian and Scottish standards having incorporated what Biesta (2009) calls the learnification of education. It would appear that learnification is underpinned by paradigmatic knowledge that promotes effective teaching as reliant on elements that can be measured. In doing so, these two standards appear to promote these elements as a key to what should be professionally valued by the NQT.

Phase 2: Results of coding for human elements and/or paradigmatic knowledge

In the second phase of data analysis, the Australian and Scottish standards, continue to emphasise paradigmatic knowledge of teaching and learning-more so than the Swedish standards. Our line by line coding highlights the extent to which a universal case is presented to NQTs (see Table 2). There are many instances of this, particularly in the Scottish teacher standards, where NQTs are expected to have a "secure and detailed understanding of the principles of curriculum design and can apply them in any setting where learning takes place" (standard 2.1.1, our emphasis). Although this is less evident in the Australian standards, it conveys a similar message to NQTs. A key finding is that this is not evident at all in the Swedish standards, which consequently sets this nation's standards apart from the other two countries.

The element actions are directly evident appears in all the standards, albeit to varying degrees, and is associated with references to knowledge construction and transmission to students and evidence of their learning. This suggests that paradigmatic knowledge is applied in the main, to teaching and learning. More importantly, learning is only recognisable if it is explicitly evident, as in the Australian standards. Here, NQTs are expected to "evaluate personal teaching and learning programmes using evidence, including feedback from students and student assessment data, to inform planning" (3.6). Although this element appears in the Scottish standards, the difference is that NQTs have to use evidence to "...justify what is taught within the curricular areas, in relation to the curriculum and the relevance to the needs of all learners" (2.1.3). Unlike the other two nations' 
Table 2 The number and percentages for the coding of contextual professionalism and paradigmatic knowledge in the three national NQT standards (excluding headings and introductory texts)

Number of references in each standard in each country and \% of that country's standard coded for that code

Total no. of Australia Scotland Sweden references

\begin{tabular}{|c|c|c|c|c|}
\hline Paradigmatic knowledge & 106 & $\begin{array}{l}31 \\
\quad(54 \%)\end{array}$ & $\begin{array}{l}72 \\
(76 \%)\end{array}$ & $3(9 \%)$ \\
\hline Generalisability-Universal case & 51 & $9(16 \%)$ & ${ }^{42}(42 \%)$ & - \\
\hline $\begin{array}{l}\text { Actions are directly evidenced (focus on actions/ } \\
\text { strategies) }\end{array}$ & 45 & $\begin{array}{l}17 \\
(30 \%)\end{array}$ & 26 & $2(6 \%)$ \\
\hline $\begin{array}{l}\text { People free notions-Theoretical ideas, and technical } \\
\text { procedures emphasised/valued over the individual }\end{array}$ & 10 & $5(8 \%)$ & $4(7 \%)$ & $1(3 \%)$ \\
\hline $\begin{array}{l}\text { Timelessness valued-casual links emphasised rather } \\
\text { than working with ambiguity }\end{array}$ & - & - & - & - \\
\hline Contextual professionalism & 93 & $\begin{array}{l}20 \\
(37 \%)\end{array}$ & ${ }^{40}(38 \%)$ & 33 \\
\hline $\begin{array}{l}\text { A sense of past and present and future events unfold } \\
\text { over time }\end{array}$ & 5 & $1(2 \%)$ & $3(3 \%)$ & $1(3 \%)$ \\
\hline $\begin{array}{l}\text { Meaning behind actions (personal and social } \\
\text { interactions foci) }\end{array}$ & 22 & $2(4 \%)$ & (12\%) & $9(26 \%)$ \\
\hline Person in a process of change & 12 & $5(8 \%)$ & $3(3 \%)$ & $4(7 \%)$ \\
\hline Person in context & 54 & $\begin{array}{l}12 \\
(24 \%)\end{array}$ & 23 & $19(70 \%)$ \\
\hline
\end{tabular}

Percentages in the table do not add up to 100, as the percentages relate to what percentage of the total document has been coded for that code. Not every sentence of each standard is coded, while some sentences are coded for two or more categories. For example, a section may have been coded for both 'universal case' and 'people free notions are valued' and therefore overlap

standards, paradigmatic knowledge appears in only one Swedish standard, where the NQT is required to assess "how effective different teaching strategies are..." (24.2).

The results indicate that the Australian standards put slightly more emphasis on the value of people free notions. Some of these standards reduce NQTs' practices to tips and tricks (strategies). One interpretation of this is that NQTs are positioned as technical learning strategists, in that they are instructed to "...Organise content into coherent, well-sequenced learning and teaching programmes" and "Maintain student safety, ensure students' well-being and safety within school by implementing school and/or system, curriculum and legislative requirements" (2.2). In these directive instances, teaching and learning references can obscure the relational act of teaching, which in turn could hamper the development of pedagogical knowledge and teachers' decisional capital. This also appears in the Scottish standards, in that NQTs are instructed to "systematically develop and use an extensive range of strategies, approaches and associated materials for formative and summative assessment purposes, appropriate to the needs of all learners and the requirements of 
the curriculum and awarding and accrediting bodies" (3.3.1). Again, there is a difference between the Australian, Scottish and Swedish standards. One of the major contrasts is the lack of command-like injunctions (e.g. "frame the teaching in accordance with the curriculum, subject or course syllabus and the knowledge requirement" 17.2) in the Swedish standards. The other difference is when Swedish NQTs are urged (in one standard) to be systematic, which is not presented as a people-free value. Rather, they are required to reflect "on their practical work individually and together with others" (24.1).

The Swedish standards emphasise contextual professionalism, in contrast to the Australian and Scottish standards. Although all the standards convey a sense of past and present and future to NQTs, they appear differently in each nation's formulations. The only country's standards where this is notably connected to the promotion of learning is Sweden's (7). The Australian standards focus on acknowledging Indigenous and Torres Strait people (2.4), while Scottish standards recognise the environment, or climate change (1). Both Australia and Scotland address this aspect somewhat superficially as content, rather than pedagogically, as in the Swedish standard.

Overall, the Swedish standards are not dominated by paradigmatic knowledge. The timelessness value cannot be identified in any of the three countries' standards. The latter may be due to the expected focus on 'here and now' activities and competencies in the assessment of NQTs and on students' results.

Meaning behind actions appears in all three countries' standards, albeit in different ways. For example, in the Swedish standard 17.1, NQTs are encouraged to take "the context and the situation" into account. But an NQT is to "be factual and objective in his or her professional work and thereby be perceived by the students as fair" (19.1) and to "understand and follow the approach to people and knowledge on which the teacher's professional ethics are based and cultivate professional ethical standpoints" (19.6). This element is overt in the Scottish standard covering Professional Values and Personal Commitment. Here, NQTs are encouraged to respect "... the rights of all learners as outlined in the United Nations Conventions on the Rights of the Child (UNCRC) and their entitlement to be included in decisions regarding their learning experiences and have all aspects of their wellbeing developed and supported." Similar evidence is found in the Australian standards (1.5), where NQT teaching activities are "developed as a result of collaborative planning or consultation with the ESL teacher/Counsellor/Aboriginal Education Assistant, Gifted and Talented Coordinator, Learning Support Coordinator."

Again, person in a process of change is evident across the three countries' standards, but projected differently. For example, the Swedish standard encourages the NQT to "discuss with the student what knowledge he or she should be able to develop and how education shall be carried out" (17.3). Teachers are expected to "involve the student in planning and develop the student's ability to learn, both independently and together with others" (17.4) and to "develop the student's ability to detect problems and find solutions to them" (17.5). The Swedish context conveys a strong human element to the NQT by highlighting students as being in a process of change. An example in an Australian standard (6.3) highlights how teachers are 
required to "contribute to collegial discussions and apply constructive feedback from colleagues to improve professional knowledge and practice." It is difficult here to find examples of students being in a process of change. There is evidence in the Scottish standards that teachers and learners are in a process of change as they "critically examine the connections between personal and professional attitudes and beliefs, values and practices to effect improvement and, when appropriate, bring about transformative change in practice" (1). NQTs are encouraged to "use the results of assessment to identify development needs at class, group and individual level and as a basis for dialogue with learners about their progress and targets" (1).

Person in context appears in all three standards when the language is more personalised. Again, this element is conveyed differently. For example, in the Scottish standards (2.1.4) the emphasis is on NQTs' knowledge of "how to promote and support the cognitive, emotional, social and physical well-being of all learners, and demonstrate a commitment to raising all learners' expectations of themselves." The Swedish standards also contain many references to the person in context, which covers both teachers and students. For example, NQTs are expected to "Assess and document the individual student's needs and adapt the teaching to the individual, the student group, the group, the context and the situation, so that each student is able to develop as much as possible in relation to the curriculum, subject or course syllabus and the knowledge requirements" (17.1) and to "discern when there is a need for support from another teacher or another specialist occupational group" (18.3). Although this element appears less in the Australian standards, it is similar to the Scottish standard, but focuses more on students in context rather than teachers in context. An Australian example of this is that NQTs are required to "design and implement teaching strategies that are responsive to the learning strengths and needs of students from diverse linguistic, cultural, religious and socioeconomic backgrounds" (1.3). However, the Australian standards differ from the Scottish ones in that there is no emphasis on the development of children's well-being.

\section{Discussion}

\section{Contextual professionalism and paradigmatic knowledge}

When analysing the content of the standards we also considered the discourse(s) underlying them (Ball 1993). The teacher standards documents suggest which narrative is the most dominant and how this influences the way in which teaching and learning are represented. We approached the standards as a policy text and were conscious that "we read and respond to policies in discursive circumstances that we cannot, or perhaps do not, think about” (Ball 1993, p. 15). We adopted Ball's (1993) argument that "the effect of policy is primarily discursive, it changes the possibilities we have for thinking "otherwise" (p. 15). The findings suggest that teacher standards, as a policy, have the potential to limit NQTs' responses to educational change and can lead to misunderstandings about what the standards are and do (Ball 1993). Further, the standards discourse "may have the effect of redistributing 'voice'. So that it does not matter what some people say or think, only 
certain voices can be heard as meaningful or authoritative" (Ball 1993, p. 15). With teacher standards, it is the paradigmatic mega-narrative that is heard. Standards without the contextual professionalism emphasis could silence the teacher and or the learners'/students' experiences.

The findings indicate that the extent of contextual professionalism and paradigmatic knowledge varies between the three countries' standards. The Australian and Scottish standards emphasise paradigmatic knowledge regarding teaching quality, which could potentially normalise teaching as a paradigmatic endeavour. The paradigmatic mega-narrative occurs to a lesser extent in the Swedish standards, which instead emphasises person in context and meaning behind action. These occur to a lesser extent in the Scottish and Australian standards.

The Australian Institute for Teaching and School Leadership (AITSL) paradigmatic mega-narrative is underpinned by a belief that quality teaching is promoted by "evidence-based instructional strategies and techniques" (Cole 2012). Ironically, while this mega-narrative directs NQTs to value empirical evidence, there is a paucity of empirical evidence to show a causal link between prescribed standards and improved teacher quality (Santoro and Kennedy 2016). However, according to the AITSL, standards provide:

a framework that makes clear the knowledge, practice and professional engagement required across teachers' careers. They present a common understanding and language for discourse between teachers, teacher educators, teacher organisations, professional associations and the public. (AITSL 2011, p. 32)

This universal claim is contested when it is contextualised and applied in practice. For instance, the formulations of the standards have to be interpreted by every single teacher. This universalisation downplays individuals' pedagogical and contextual knowledge and decisional capital. The clone-like approach to teachers and teaching is unlikely to result in a deep and elaborated understanding of pedagogy and context. Kennedy (2014) argued that a standards-based approach to professional learning reduces teaching from being "a complex, context-specific political and moral endeavour" (p. 342). This mega-narrative is antithetical to its aims, as it is claimed to most probably diminish teachers' professional learning by focusing on "decontextualised prescriptions or activities that may be experienced as acts of compliance" (Reich et al. 2015, p. 132). The AITSL's (2011) claim of 'a common understanding' that 'makes clear the knowledge' is probably overestimated, although these are vital elements of the mega-narrative's purpose, which is to legitimise teacher standards. In Scotland, the Standard for Full Registration functions as the regulatory benchmark for competency to teach and as a tool for professional learning. We argue below that these two simultaneous functions are problematic.

In considering contextual professionalism and paradigmatic knowledge across the three nations' standards, we see a repetition in the arguments for and against standards: 
there are tensions between the statements inscribed by professional bodies and organisations and the accounts of professional practices elicited from work itself. The former prescribes what should be learned, or more particularly the competencies that should be demonstrated. The latter provides an account of the practices and the learning entwined in it. (Reich et al. 2015, p. 138)

Paradigmatic knowledge, particularly in Scotland and Australia, suggests how a teacher should operate, rather than provide autonomy and discretion in how to practice. The more dominant paradigmatic directives of the NQT standards conceal and thereby "overlooks the complexity of teachers' work and the strongly contextualised situations in which moral, social and political decisions about subject, person and groups are made and remade in the everyday life of teachers and student teachers" (Winter 2000, pp. 155-156). The rhetoric of the standards is questionable, especially with regard to how they support NQTs' professional development, and particularly as there is minimal recognition that teaching and learning is a "human and messy business" and that "one size never fits all" (Mockler 2013, p. 37). However, as Mockler (2013) highlighted, this is "at cross purposes with the neoliberal desire to catalogue and standardise practice" (p. 37).

We suggest that teacher standards potentially endanger the retention and development of NQTs in that they downplay classrooms as places where the unexpected often occurs and that teaching is learning from experience and adapting to new situations (Reich et al. 2015). The Scottish Standard for Full Registration is very detailed when it comes to specifications of practice. The standard concentrates on "delineating minor aspects of practice precisely, rather than complex practices in context" (Forde et al. 2016, p. 22). The over-simplification reduces contextualisation and the individualisation of practice. Paradigmatic knowledge is not as noticeable in the Swedish standards, where there is a greater emphasis on context, the individualisation of practice and teaching and learning as relational. The Swedish standards' discourse on what quality teaching looks like differs significantly from the mega-narrative in the other two nations' standards.

The standards differ in length and in the amount of detail provided. First, the length of the standards and their precision say something about what kind of space a teacher is given to interpret, understand and enact professional practice (Forde et al. 2016). The provision of detailed instructions could be regarded as indications of a 'governed' or 'de-professionalised' teacher with limited professional space or autonomy. Standards with more general formulations could be understood as having confidence in the teaching corps and that teachers are able to interpret the standards 'correctly' and professionally. These less detailed and more open formulations potentially allow teachers to professionally interpret the standard and enact their professional critique. In this respect, the very detailed Scottish standards could be understood as positioning NQTs as technicians with little room for professional interpretation and judgement. The Swedish standards have more general formulations, thus potentially allowing greater space for professional interpretation. Alternatively, the general expressions of intent in the Swedish standards could give rise to greater uncertainty and thus make the assessment of NQTs too complicated and even unfair. The Australian standards, although less descriptive, 
potentially implying room for interpretation, are misleading in this respect, when considering the dominant technical language. They too are more likely to position the NQTs as technicians.

\section{Why have teacher standards been abolished in Sweden but not in Australia or Scotland?}

Australia and Sweden as late adopters have most likely borrowed policies (standards), learned from others (Chakroun 2010), such as Scotland, and adjusted the standards to their national circumstances and contexts. Over the years, the Scottish teacher standards have had minimal revisions and are still operative- as are the Australian standards. However, in Sweden, the 2011 standards and the evaluation of NQTs' competences were discontinued in July 2014. This policy retreat and educational change took place despite the strong mega-narratives that had been used to legitimise their implementation. The reasons for no longer using the standards were that they were a 'practical' problem in that not all NQTs were offered evaluative probation placements to secure registration, that they made teaching less attractive (Ministry of Education and Research 2013) and that the evaluation had increased principals' workloads. The evaluation of teachers was an uncommon phenomenon; principals were uncomfortable with the task of gatekeeping, which they regarded as a task of teacher education departments (Gerrevall 2014; The RAOL-Project). The policy retreat may also have been a result of political bargaining, with promises of other reforms to enhance quality teaching and the fact that the standards had not yet become institutionalised.

In Sweden, the responsible authority-the Swedish National Agency for Education-is not just in charge of teacher standards and the administration of teacher registration (which is still operative), but also has a range of other functions. It compiles systematic reviews, general guidelines and national tests, has responsibility for official education statistics and for participation in international tests. In Scotland, the General Teaching Council for Scotland (GTCS) is responsible for teacher induction, teacher standards and teacher registration. Therefore, a policy retreat and a move away from teacher standards in Scotland is less likely, because then the raison d'être of the GTCS (or its successor the proposed new Education Workforce Council) would no longer exist. Similarly, the Australian Institute for Teaching and School Leadership (AITSL), established in 2010, is tasked to "foster and drive a culture of high quality professional learning that would change the attitudes and practices of teachers and school leaders" (Cole 2012, p. 7). In order to achieve this, AITSL (2011) engages in "developing and maintaining rigorous national professional standards for teachers and school leaders" (p. 12). In short, the support to abandon teacher standards is absent.

\section{Implications for NQTs, mentors and principals}

A focus on the observable, measureable professional skills of an NQT means that qualities that are more difficult to define, such as empathy, may be overlooked (Webster-Wright 2009). Paradigmatic knowledge within the standards does not 
acknowledge teachers' emotional and relational experiences, by which NQTs can discover their own "personal commitment" and teaching purpose (McNally 2006, p. 89). The experience of an NQT can be seen as one of:

becoming rather than of incremental learning; it is about who you are as much as what you know, perhaps better understood as an ontological rather than epistemological process. (McNally 2006, p. 89)

The standards in the three countries are partly designed as instruments to move a student teacher to being a fully qualified teacher. A key question remains as to how these standards are enacted and played out in practice. In Scotland, the Standard for Full Registration is seen as something that is "more about ticking boxes than critical reflection" (Shanks et al. 2012, p. 194; McNally et al. 2009), while some (Forde et al. 2016) have argued that this particular standard could be embraced as a professional learning tool. Here, it is suggested that although NQTs in Scotland are expected to cover each of the standards in their weekly mentor meetings, there is little evidence to suggest that this occurs (Forde et al. 2016). In Sweden, most of the research focus has been on the implementation of the reform and less on how mentoring or assessment are carried out in practice. However, research has indicated that many Swedish principals have experienced strengthened relationships with NQTs during the probationary year and that only a few have experienced strained relations (Fransson et al. 2017). In Australia, mentors are assigned to NQTs and work with them to collect and document evidence of proficiency. Mentors are directed to focus on the paradigmatics of teaching and learning in their dual role of support and formal assessment. In Sweden, the formal assessment of NQTs places mentors in a difficult position in relation to mutual trust and authenticity (Fransson 2010). Overall, the standards do not seem to recognise NQTs as being in a vulnerable position, thereby making it difficult for them to be completely honest with a mentor who is also responsible for their assessment (Shanks 2014).

The implications of our research are that NQTs, mentors and principals must know how the standards position their working relationships and professional development. Mentors and principals may have to deal with the dilemma of an overemphasis of paradigmatic knowledge in NQT standards that may conceal the contextual elements that inform professionalism and decision-making. For the Swedish case, it could be argued that there is an over-emphasis on contextual professionalism, which may conceal paradigmatic knowledge (of, for example, professional and collective routines and ethical guidelines). The fact that the Swedish National Agency for Education has developed additional guidelines and checklists for principals when assessing NQTs supports this claim.

\section{Limitations of the study}

This is a qualitative interpretative study of the standards, where coding for contextual professionalism and paradigmatic knowledge were crucial lenses in the investigation. We have worked collaboratively on the conceptual framing, analysis and writing stages and our objective has been to be as explicit as possible when 
describing the codes and interpretations. The collaboration required continual debate and analysis when interpreting analysis for example: how should the term "all learners" in the Scottish standards be understood? Should it be interpreted as 'one size fits all', which signals paradigmatic knowledge, or as an appeal for inclusiveness, which is more about contextual professionalism? Interpretations required the consideration of the wider textual context. Depending on the standard's full text and meaning, in the example of 'all learners', sentences have sometimes been interpreted as reflecting paradigmatic knowledge and sometimes as contextual professionalism. In a similar way, differences in language could lead to overinterpretation (cf. Biesta 2009). For instance, the same phenomenon may be addressed but named differently, e.g. Scottish teachers talk about 'pupils' when Australians refer to them as 'students'. As such, challenges that are an integral part of qualitative research could be regarded as limitations. Another possible limitation is that the study focuses on national teacher standards that that have been expressly developed at a generic level and could, therefore, be regarded as necessarily superficial or context-free in order to be applicable across multiple and differing contexts, where numerous references to context are neither expected nor possible.

\section{Conclusion}

We have highlighted the different reasons for educational change by the implementation of teacher standards. These are: to improve teacher quality, to state what teachers should do, to control entry into the profession, to regulate the profession and to focus on teachers' professional development. By using Olson and Craig's (2009a, b) conceptual framing, we have seen that in Australia and Scotland, teacher standards focus on the measurable and overt actions that teachers should perform, rather than the more elusive contextual and emotional elements of teaching, which are hard to define and even harder to assess.

Paradigmatic knowledge overshadows the small everyday stories of teachers and places restrictions on the professional learning of NQTs. This could result in teachers' decisional capital being eroded and the scope for leadership, teaching, learning and educational change being reduced to technical expertise.

\section{Future research}

This comparative study contributes knowledge about teacher standards and shows how standards can project different views of the professional teacher. However, more research is needed to compare how standards construct teachers and learning in different national and cultural contexts and to determine how teachers interpret their contexts and use the standards. Some research has focused on how meganarratives travel and are incorporated into standards, but again more work on this is needed. Further research is also required on the ways in which standards for NQTs influence the mentoring process, how they inform the supportive and evaluative 
dimensions of mentoring and, if applicable, how they affect the practice of assessing NQTs.

Open Access This article is distributed under the terms of the Creative Commons Attribution 4.0 International License (http://creativecommons.org/licenses/by/4.0/), which permits unrestricted use, distribution, and reproduction in any medium, provided you give appropriate credit to the original author(s) and the source, provide a link to the Creative Commons license, and indicate if changes were made.

\title{
Appendix: Descriptions of the codes for human elements (contextual professionalism) and paradigmatic knowledge
}

\author{
Human element (contextual professionalism) codes and identification \\ descriptions
}

A sense of the past and present and future events unfold over time (Olson and Craig 2009a, p. 550) does not represent time as static or linear, but recognises how the past informs the present, which eventually informs the future. A number of theories align with this conceptual framing (see for example, Gebser 1949/1985; Bourdieu 2013).

Person in the process of change (Olson and Craig 2009a, p. 550) to be recognised when teachers and/or students are seen as entities, rather than objects, and there is no such thing as perfection. For example, who you are today may not necessarily be who you think you are tomorrow. In identity theory, there is a discussion about people being identities, not an identity, and the human element in this category conveys this.

The human element of meaning behind actions (Olson and Craig 2009a, p. 550) can be identifiable when there is reference to people's actions not being taken at face value and the focus is on the interaction.

Person in context (Olson and Craig 2009a, p. 550) can be identified when individuals and their contexts are taken into consideration, for example the size of the class, who is in the class and the ethos or values of the school. Individuals engage with their context, which is the focus of symbolic interaction theory.

When educational issues are viewed as wicked problems (Grint 2010) the human element is acknowledged and the complexity of teaching young people from different backgrounds in diverse school cultures and micro-political environments are highlighted. This means that the issues that arise often need to be repeatedly resolved, depending on how often and when they emerge and in which context.

\section{Paradigmatic knowledge codes and identification descriptions}

Timelessness being valued (Olson and Craig 2009a, p. 550) is identified when causality is promoted about what needs to happen to be an effective or quality teacher, or promotes/implies how a specific action will lead to improved students' outcomes.

People free notions are valued, can be identified when theoretical ideas and technical procedures are emphasised/valued over the individual, i.e. that people are 
treated as objects rather than agents who can enact or make agentic decisions. Further evidence is when the system is valued more highly than the people within it.

Actions are directly evident (Olson and Craig 2009a) when decisions are understood by removing or ignoring ambiguity. A standard would reflect a belief that what we see is what there is and that it does not engage with personal and social interactions, which cannot always be measured.

Universal case (Olson and Craig 2009a) is the search for generalisability, e.g. promotes a one size fits all model/approach. A standard that exhibits this paradigmatic knowledge projects educational issues as tame problems, i.e. that there is always an answer and it is simply a matter of finding the right one and applying it so that everything will be resolved. A tame approach to a problem (Grint 2010) requires project management thinking, which is defined by linear thinking, timeless, valueless and people-free notions.

\section{References}

Alberta Education. (2013). Teaching quality standard applicable to the provision of basic education in Alberta. Ministerial order (\#016/97), revised October 2013.

Australian Institute for Teaching and School Leadership (AITSL). (2011). Annual Report 10/11. Melbourne: AITSL.

Australian Institute for Teaching and School Leadership (AITSL). (2015). Insights. Evaluation of the implementation of the Australian professional standards for teachers. Interim report 2-2014 key findings. AITSL: Melbourne.

Ball, S. J. (1993). What is policy? Texts, trajectories and Toolboxes. Discourse: Studies in the Cultural Politics of Education, 13(2), 10-17. https://doi.org/10.1080/0159630930130203.

Bazeley, P., \& Jackson, K. (2013). Qualitative data analysis with NVivo (2nd ed.). London: Sage.

Berliner, D. C. (2005). The near impossibility of testing for teacher quality. Journal of Teacher Education, 56(3), 205-213.

Biesta, G. (2009). Good education in an age of measurement: On the need to reconnect with the question of purpose in education. Educational Assessment, Evaluation and Accountability, 21(1), 33-48.

Bourdieu, P. (2013). Symbolic capital and social classes. Journal of Classical Sociology, 13(2), $292-302$.

Broadbent, C., \& Gallagher, M. (2013). Australian professional standards and professional identity: The link to improving teacher quality and educational outcomes. Paper presented at the ISATT conference, University of Ghent, Belgium, July 1-5.

Bruner, J. (1986). Actual minds, possible worlds. London: Harvard University Press.

Chakroun, B. (2010). National qualification frameworks: From policy borrowing to policy learning. European Journal of Education, 45(2), 199-216.

Christie, F., \& O'Brien, J. (2005). A continuing professional development framework for Scottish teachers: Steps, stages, continuity or connections? In A. Alexandrou, K. Field, \& H. Mitchell (Eds.), The continuing professional development of educators: Emerging European issues (pp. 93-110). Oxford: Symposium Books.

Clarke, M., \& Moore, A. (2013). Professional standards, teacher identities and an ethics of singularity. Cambridge journal of education, 43(4), 487-500. https://doi.org/10.1080/0305764X.2013.819070.

Cohen, D. K., \& Garet, M. S. (1975). Reforming educational policy with applied social research. Harvard Educational Review, 45(1), 17-43. https://doi.org/10.17763/haer.45.1.816r0525w1283044.

Cole, P. (2012). Professional learning for school effectiveness in Australia: What does it take?. Melbourne: Australian Institute for Teaching and School Leadership (AITSL).

Colorado Department of Education. (2017). State model evaluation system for teachers. http://www.cde. state.co.us/educatoreffectiveness/smes-teacher\#TQS. Accessed April 24, 2017. 
Dall'Alba, G., \& Sandberg, J. (2006). Unveiling professional development: A critical review of stage models. Review of Educational Research, 76(3), 383-412. https://doi.org/10.3102/ 00346543076003383.

Delandshere, G., \& Arens, S. A. (2001). Representations of teaching and standards-based reform: Are we closing the debate about teacher education? Teaching and Teacher Education, 17(5), 547-566.

Down, B. (2012). Reconceptualising teacher standards: Authentic, critical and creative. In B. Down \& J. Smyth (Eds.), Critical voices in teacher education, explorations of educational purpose (pp. 63-80). Dordrecht: Springer.

Draper, J., Fraser, H., \& Taylor, W. (1997). Teachers at work: Early experiences of professional development. British Journal of In-service Education, 23(2), 283-295.

Draper, J., \& O'Brien, J. (2006). Induction: Fostering career development at all stages. Edinburgh: Dunedin Academic Press.

European Commission. (2013). Supporting teacher competence development for better learning outcomes. Education and Training. European Commission.

Exley, S., Braun, A., \& Ball, S. (2011). Global education policy: Networks and flows. Critical Studies in Education, 52(3), 213-218.

Forde, C., McMahon, M. A., Hamilton, G., \& Murray, R. (2016). Rethinking professional standards to promote professional learning. Professional Development in Education, 42(1), 19-35. https://doi. org/10.1080/19415257.2014.999288.

Fransson, G. (2010). Mentors assess mentees? An overview and analyses of the mentorship role concerning newly qualified teachers. European Journal of Teacher Education, 33(4), 375-390. https://doi.org/10.1080/02619768.2010.509426.

Fransson, G., Frelin, A., \& Grannäs, J. (2017). Rektorer och lämplighetsprövningen av nyutbildade lärare [Head teachers and the evaluation of newly qualified teachers]. Scientific report no. 45. Gävle: Gävle University Press.

Gebser, J. (1949/1985). The ever-present origin. Athens, OH: Ohio University Press.

General Teaching Council For Scotland. (2002). The standard for full registration (1st ed.). Edinburgh: General Teaching Council for Scotland.

General Teaching Council For Scotland. (2006). The standard for full registration (2nd ed.). Edinburgh: General Teaching Council for Scotland.

General Teaching Council For Scotland. (2012). The standard for full registration (3rd ed.). Edinburgh: General Teaching Council for Scotland.

Gerrevall, P. (2014). Let the right one out. On the assessment of teachers' suitability during their induction program. Paper presented at the conference 'Teachers Matter', October 23-24, Växjö, Sweden.

Goodwin, A. L. (2008). Defining teacher quality. Is consensus possible? In M. Cochran-Smith, S. FeimanNemser, \& J. D. McIntyre (Eds.), Handbook of research on teacher education: Enduring questions in changing contexts (3rd ed., pp. 399-403). New York: Routledge.

Grint, K. (2010). The cuckoo clock syndrome: Addicted to command, allergic to leadership. European Management Journal, 28, 306-313. https://doi.org/10.1016/j.emj.2010.05.002.

Groundwater-smith, S., \& Sachs, J. (2002). The activist professional and the reinstatement of trust. Cambridge journal of education, 32(3), 341-358.

Halverson, R. R., \& Clifford, M. A. (2006). Evaluation in the wild: A distributed cognition perspective on teacher assessment. Educational Administration Quarterly, 42(4), 578-619.

Hattie, J. (2009). Visible learning: A synthesis of over 800 meta-analyses relating to achievement. London, New York: Routledge.

Hattie, J. (2012). Visible learning for teachers: Maximizing impact on learning. London: Routledge.

Hsieh, H.-F., \& Shannon, S. E. (2005). Three approaches to qualitative content analysis. Qualitative Health Research, 15(9), 1277-1288. https://doi.org/10.1177/1049732305276687.

Imig, D. G., \& Imig, S. R. (2008). From traditional certification to competitive certification. In M. Cochran-Smith, S. Feiman-Nemser, \& J. D. McIntyre (Eds.), Handbook of research on teacher education: Enduring questions in changing contexts (3rd ed., pp. 886-907). New York: Routledge.

Ingvarson, L. (1998). Professional development as the pursuit of professional standards: The standardsbased professional development system. Teaching and Teacher Education, 14(1), 127-140. https:// doi.org/10.1016/S0742-051X(97)00065-6.

Kennedy, A. (2014). Models of continuing professional development: A framework for analysis. Professional Development in Education, 40(3), 336-351. https://doi.org/10.1080/19415257.2014. 929293. 
Lingard, B. (2010). Policy borrowing, policy learning: Testing times in Australian schooling. Critical Studies in Education, 51(2), 129-147.

MacBeath, J. (2008). Leading learning in the self-evaluating school. School Leadership \& Management, 28(4), 385-399.

Mahony, P., \& Hextall, I. (2000). Reconstructing teaching: Standards, performance and accountability. London: Routledge.

Mayer, D., Mitchell, J., Macdonald, D., \& Bell, R. (2005). Professional standards for teachers: A case study of professional learning. Asia-Pacific Journal of Teacher Education, 33(2), 159-179. https:// doi.org/10.1080/13598660500121977.

McNally, J. (2006). From informal learning to identity formation: A conceptual journey in early teacher development. Scottish Educational Review, 37(Special edition), 79-89.

McNally, J., Blake, A., Corbin, B., \& Gray, P. (2008). Finding an identity and meeting a standard: Connecting the conflicting in teacher induction. Journal of Education Policy, 23(3), 287-298.

McNally, J., Blake, A., \& Reid, A. (2009). The informal learning of new teachers in school. Journal of Workplace Learning, 21(4), 322-333.

Miles, M. B., Huberman, A. M., \& Saldaña, J. (2014). Qualitative data analysis: A methods sourcebook (3rd ed.). Los Angeles: Sage.

Ministry of Education and Research. (2013). Ändrade regler om introduktionsperiod och legitimation för lärare och förskollärare [Changed rules for the probationary year and the registration of teachers and preschool teachers]. Promemoria 17.12.2013 U2013/7686/S. Stockholm: Ministry of Education and Research.

Mockler, N. (2013). Teacher professional learning in a neoliberal age: Audit, professionalism and identity. Australian Journal of Teacher Education, 38(10), 35-47.

Møller, J. (2009). School leadership in an age of accountability: Tensions between managerial and professional accountability. Journal of Educational Change, 10, 37-46.

Nordin, A. (2014). Crisis as a discursive legitimation strategy in educational reforms: A critical policy analysis. Education Inquiry, 5(1), 109-126.

Olson, M. R., \& Craig, C. J. (2009a). "Small” stories and mega-narratives: Accountability in Balance. Teachers College Record, 111(2), 547-572.

Olson, M., \& Craig, C. (2009b). Converging milieus and educative conundrums. Teaching and Teacher Education, 25, 1077-1085.

Paulus, T. M., Lester, J. N., \& Dempster, P. G. (2014). Digital tools for qualitative research. London: Sage.

Reich, A., Rooney, D., \& Boud, D. (2015). Dilemmas in continuing professional learning: Learning inscribed in frameworks or elicited from practice. Studies in Continuing Education, 37(2), 131-141.

Sachs, J. (2003). Teacher professional standards: Controlling or developing teaching? Teachers and Teaching, 9(2), 175-186.

Sahlberg, P. (2010). Rethinking accountability in a knowledge society. Journal of Educational Change, $11(1), 45-61$.

Santoro, N., \& Kennedy, A. (2016). How is cultural diversity positioned in teacher professional standards? An international analysis. Asia-Pacific Journal of Teacher Education, 44(3), 208-223. https://doi.org/10.1080/1359866X.2015.1081674.

Santoro, N., Reid, J.-A., Mayer, D., \& Singh, M. (2012). Producing 'quality' teachers: The role of teacher professional standards. Asia-Pacific Journal of Teacher Education, 40(1), 1-3. https://doi.org/10. 1080/1359866X.2012.644508.

Shanks, R. (2014). A study of learners' situational vulnerability: New teachers in Scotland. Education in the North, 21. http://www.abdn.ac.uk/eitn/display.php?article_id=93.

Shanks, R., Robson, D., \& Gray, D. (2012). New teachers' individual learning dispositions: A Scottish case study. International Journal of Training and Development, Special Issue on Continuing Professional Development, 16(3), 183-199.

Smith, E. (2008). Raising standards in American schools? Problems with improving teacher quality. Teaching and Teacher Education, 24(3), 610-622.

SOU. (2008). Legitimation och skärpta behörighetsregler [Swedish Government Official Report 2008:52. Registration and stricter qualifying rules]. Stockholm: Ministry of Education and Research.

Statutes of the National Agency for Education. (2011). The National Agency for Education's guidelines on the induction period and competence profiles for teachers and preschool teachers. SKOLFS 2011:37. Stockholm: The Swedish National Agency for Education. 
The RAOL-Project. Head masters working condition and the evaluation of NQTs. http://www.hig.se/ research/raol. Accessed Aug 18, 2017.

Timperley, H. (2011). A background paper to inform the development of a national professional development framework for teachers and school leaders. Melbourne: Australian Institute for Teaching and School Leadership (AITSL).

Tolofari, S. (2005). New public management and education. Policy Futures in Education, 3(1), 75-89.

Tuinamuana, K. (2011). Teacher professional standards, accountability and ideology: Alternative discourses. Australian Journal of Teacher Education, 36(12), 72-82.

US Department of Education. (2002). No child left behind. Retrieved November 3, 2015 from www2.ed. gov/policy/elsec/leg/esea02/index.html.

Waldow, F., Takayama, K., \& Sung, Y.-K. (2014). Rethinking the pattern of external policy referencing: Media discourses over the "Asian Tigers"' PISA success in Australia, Germany and South Korea. Comparative Education, 50(3), 302-321. https://doi.org/10.1080/03050068.2013.860704.

Webster-Wright, A. (2009). Reframing professional development through understanding authentic professional learning. Review of Educational Research, 79(2), 702-739.

Winter, C. (2000). The state steers by remote control: Standardising teacher education. International Studies in Sociology of Education, 10(2), 153-175. 